\title{
Perbedaan Pengaruh Terapi Napas Dalam dan Terapi Relaksasi Otot Progresif terhadap Penurunan Tekanan Darah Lansia Hipertensi di Posyandu Lansia Kelurahan Surau Gadang Kecamatan Nanggalo Padang Tahun 2012
}

\author{
Melda Yulinda ${ }^{a}$, Lili Fajria ${ }^{a}$ \\ Fakultas Keperawatan Universitas Andalas
}

\begin{abstract}
Hypertension is a disease that affects many elderly. Non-pharmacological management is recommended to avoid the effects of pharmacological treatment in the elderly. It can be performed by a deep breathing and progressive muscle relaxation therapy. Breathing can stimulate the release of nitric oxide to dilate the blood vessels so that blood pressure can be lowered. Progressive muscle relaxation therapy can decrease sympathetic nerve activity that causes vascular vasodilatation so that blood pressure lowered. The purpose of this study was to determine the difference in therapeutic effect of deep breathing and progressive muscle relaxation therapy for hypertensive elderly blood pressure reduction. This study used a quasiexperimental design with non-equivalent approach Comparison Group Pretest-Posttest Design using a paired $t$ test, unpaired t test and Man-Whitney test. Total sample of 30 respondents dispersed 15 people got a deep breath therapy and 15 received progressive muscle relaxation therapy. The results showed that there were reductions in blood pressure in each group with $p=0.000$ and there are differences in blood pressure reduction between treatment groups deep breath and progressive muscle relaxation therapy with $p=0.001$ and $p=0.042$ systolic. Progressive muscle relaxation therapy better at lowering blood pressure in the elderly. It is recommended to perform progressive muscle relaxation for the Nonpharmacologic treatment of hypertension in older adults with hypertension.
\end{abstract}

Key words : hypertension, eldery, deep breathing, progressive muscle relaxation

\begin{abstract}
Abstrak: Hipertensi merupakan salah satu penyakit yang banyak diderita oleh lansia. Penatalaksanaan non farmakologi dapat dilakukan dengan terapi napas dalam dan terapi relaksasi otot progresif. Teknik napas dalam dapat merangsang keluarnya Oksida Nitrit yang dapat mendilatasi pembuluh darah sehingga tekanan darah dapat diturunkan. Terapi relaksasi otot progresif dapat menurunkan aktifitas saraf simpatis yang menyebabkan vasodilatasi vaskuler sehingga tekanan darah turun. Tujuan penelitian ini adalah untuk mengetahui perbedaan pengaruh terapi napas dalam dan terapi relaksasi otot progresif terhadap penurunan tekanan darah lansia hipertensi. Penelitian ini menggunakan desain quasi-eksperimen dengan pendekatan Non Equivalen Comparison Group Pretest-Posttest Design menggunakan uji t berpasangan, uji t tidak berpasangan dan uji Man-Whitney. Jumlah sampel sebanyak 30 responden tersebar 15 orang mendapat terapi napas dalam dan 15 orang mendapat terapi relaksasi otot progresif.Hasil menunjukkan terdapat penurunan tekanan darah pada masing-masing kelompok dengan $\mathrm{p}=0,000$ dan terdapat perbedaan penurunan tekanan darah antara kelompok terapi napas dalam dan terapi relaksasi otot progresif dengan $\mathrm{p}=0,001$ sistolik dan $\mathrm{p}=0,042$. Pemberian terapi relaksasi otot progresif lebih baik dalam menurunkan tekanan darah pada lansia. Disarankan untuk melakukan relaksasi otot progresif untuk penanganan hipertensi secara nonfarmakologis pada lansia dengan hipertensi.
\end{abstract}

Kata kunci: hipertensi, lansia, napas dalam, relaksasi otot progresif 


\section{PENDAHULUAN}

Proses menua adalah suatu proses menghilangnya secara perlahan-lahan kemampuan jaringan untuk memperbaiki diri/mengganti dan mempertahankan fungsi normalnya sehingga tidak dapat bertahan terhadap infeksi dan memperbaiki kerusakan yang diderita (Nugroho, 2000). Di Indonesia jumlah penduduk lansia adalah 18,57 juta jiwa pada tahun 2010, meningkat sekitar 7,93\% dari tahun 2000 yang sebanyak 14,44 juta jiwa (Badan Koodinasi Keluarga Berencana Nasional [BKKBN], 2012).

Salah satu penyakit yang sering diderita oleh lansia adalah hipertensi. Hipertensi merupakan tekanan darah di atas normal, yaitu 140/90 $\mathrm{mmHg}$ yang merupakan faktor risikoutama untuk stroke, gagal jantung dan penyakitkoroner (Kaplan dalam Kuswardhani, 2006). Berdasarkan data dari Framingham, usia 55 tahun dengan tekanan darah normal mempunyai resiko mengalami hipertensi seumur hidup sebesar $90 \%$ (Vasan, 2002; JNC, 2003 dalam Meiner, 2011).

Pengobatan hipertensi terdiri dari terapi farmakologis dan non farmakologis. Untuk mencegah efek farmakologi, lansia dianjurkan untuk melakukan Terapi non farmakologik diantaranya relaksasi. Dua diantara teknik relaksasi di atas yang mudah dilakukan adalah napas dalam dan relaksasi otot progresif.

Terapi napas dalam bermanfaat untuk menurunkan tekanan darah karena bernapas secara dalam dapat merangsang munculnya oksida nitrit yang berfungsi sebagai vasodilatator sehingga dapat menurunkan tekanan darah (Clark,2012 dan Wikipedia, 2012). Sedangkan teknik relaksasi otot progresif meliputi suatu latihan peregangan otot dan olah pernapasan yang dilakukan untuk menghasilkan respon yang dapat memerangi respon stres dan menurunkan aktifitas saraf simpatis sehingga dapat menurunkan tekanan darah, (Smeltzer \& Bare, 2002).
Data yang diperoleh dari Dinas Kesehatan Kota Padang tahun 2011, hipertensi merupakan penyakit nomor tiga terbanyak yang diderita oleh lansia. Jumlah kunjungan lansia yang menderita hipertensi ke puskesmas di Kota Padang adalah sebanyak 14.696 dari 82.784 lansia atau sekitar $18 \%$ lansia dan yang terbanyak terdapat di wilayah kerja Puskesmas Nanggalo yaitu sebanyak 2112 lansia. (Dinas Kesehatan Kota [DKK] Padang, 2011).

Berdasarkan studi pendahuluan yang telah dilakukan di Wilayah Kerja Puskesmas Nanggalo, setiap tahun terjadi peningkatan kunjungan lansia dengan hipertensi yaitu 57,6 \% (2010) naik menjadi 67,4 \% (2011). Kelurahan Surau Gadang mempunyai jumlah lansia terbanyak di Nanggalo yaitu 64,59 \% dari 2916 orang lansia. Berdasarkan hasil wawancara dengan 10 lansia hipertensi di Kelurahan Surau Gadang menyatakan belum pernah mencobakan teknik napas dalam maupun relaksasi otot progresif untuk menurunkan tekanan darah.

Berdasarkan fenomena di atas, penulis tertarik untuk melakukan penelitian tentang perbedaan pengaruh terapi napas dalam dan terapi relaksasi otot progresif terhadap penurunan tekanan darah lansia hipertensi di posyandu lansia Kelurahan Surau Gadang Kecamatan Nanggalo Padang Tahun 2012. Penelitian ini bertujuan untuk menjelaskan perbedaan pengaruh terapi napas dalam dan terapi relaksasi otot progresif terhadap penurunan tekanan darah lansia hipertensi di Posyandu Lansia Kelurahan Surau Gadang Kecamatan Nanggalo Padang Tahun 2012.

\section{METODE}

Jenis penelitian ini adalah korelasional dengan desain penelitian quasi-eksperiment. Dalam peneltian ini dilihat perbedaan pengaruh terapi napas dalam dan terapi relaksasi otot progresif terhadap penurunan tekanan darah lansia hipertensi di posyandu lansia Kelurahan 
Surau Gadang Kecamatan Nanggalo Padang dengan jumlah sampel 30 lansia dengan hipertensi terseber 15 orang mendapat terapi napas dalam dan 15 orang mendapat terapi relaksasi otot progresif. Penelitian ini dilaksanakan pada bulan Juli 2012 hingga Februari 2013. Pengumpulan data dilakukan secara langsung pada subjek penelitian dimana tekanan darah subjek penelitian diukur dengan menggunakan tensimeter digital sebelum dan sesudah intervensi. Analisa data univariat dilakukan menggunakan distribusi frekuensi, analisa bivariat menggunakan uji t berpasangan, uji $\mathrm{t}$ tidak berpasangan dan uji Mann-Whitney.

\section{HASIL DAN PEMBAHASAN}

Berdasarkan karakteristik responden didapatkan bahwa usia responden pada kedua kelompok adalah pada rentang usia 60-64 tahun dengan masing- masing proporsi $6(40 \%)$ pada kelompok yang mendapat terapi napas dalam dan $7(46,7 \%)$ pada kelompok yang mendapat terapi relaksasi otot progresif. Selanjutnya berdasarkan jenis kelamin, responden terbanyak pada kedua kelompok adalah perempuan dengan proporsi masing-masing $11(73,3 \%)$ pada kelompok yang mendapat terapi napas dalam dan $9(60 \%)$ pada kelompok yang mendapat terapi relaksasi otot progresif. Berdasarkan aktifitas fisik, responden terbanyak adalah kelompok yang jarang melakukan aktifitas fisik dengan proporsi 7 (46,7\%) pada kelompok yang mendapat terapi napas dalam dan kelompok yang melakukan aktifitas fisik $1 \mathrm{x}$ seminggu dengan proporsi $6(40 \%)$ pada kelompok yang mendapatkan terapi relaksasi otot progresif. Berdasarkan diet responden pada kedua kelompok adalah rendah garam dengan masing- masing proporsi $8(53,3 \%)$ pada kelompok yang mendapat terapi napas dalam dan $9(60 \%)$ pada kelompok yang mendapat terapi relaksasi otot progresif. Berdasarkan riwayat merokok responden pada kedua kelompok adalah tidak pernah merokok dengan masing- masing proporsi 11 $(73,3 \%)$ pada kelompok yang mendapat terapi napas dalam dan $9(60 \%)$ pada kelompok yang mendapat terapi relaksasi otot progresif.

Tabel 1. Perbedaan Pengaruh Terapi Napas Dalam dan Terapi Relaksasi Otot Progresif Terhadap Penurunan Tekanan Darah Sistolik Lansia Hipertensi di Posyandu Lansia Kelurahan Surau Gadang Kecamatan Nanggalo Tahun 2012

\begin{tabular}{|c|c|c|c|c|c|}
\hline Kelompok & $\begin{array}{c}\text { Rata-rata } \\
\text { Penurunan } \\
\text { Tekanan Darah }\end{array}$ & \multirow{2}{*}{$\begin{array}{c}\text { Std. } \\
\text { Deviation }\end{array}$} & \multicolumn{2}{|c|}{$\begin{array}{c}\text { 95\% Confidence } \\
\text { Interval of the } \\
\text { Difference }\end{array}$} & \multirow{2}{*}{$\mathbf{p}$} \\
\cline { 4 - 5 } & 5,40 & 2,444 & Upper & Lower & \\
\hline Napas Dalam & 9,47 & 3,641 & 1.826 & 6.308 & \multirow{2}{*}{0,001} \\
\hline $\begin{array}{c}\text { Relaksasi Otot } \\
\text { Progresif }\end{array}$ & & & &
\end{tabular}

Hasil uji tes tidak berpasangan didapatkan $p$ value $=0,001(p<0,05)$, artinya terdapat perbedaan selisih penurunan tekanan darah sistolik antara responden yang mendapat terapi napas dalam dengan responden yang mendapat terapi relaksasi otot progresif. 
Tabel 2. Perbedaan Pengaruh Terapi Napas Dalam dan Terapi Relaksasi Otot Progresif Terhadap Penurunan Tekanan Darah Diastolik Lansia Hipertensi di Posyandu Lansia Kelurahan Surau Gadang Kecamatan Nanggalo Tahun 2012

\begin{tabular}{|c|c|c|c|c|}
\hline Kelompok & n & Mean Rank & Sum of Rank & p value \\
\hline Napas Dalam & 15 & 12.30 & 184.50 & \multirow{2}{*}{0.042} \\
\hline $\begin{array}{c}\text { Relaksasi Otot } \\
\text { Progresif }\end{array}$ & 15 & 18.70 & 280.50 & \\
\hline
\end{tabular}

Uji Man-Whitney didapatkan p value $=0,042 \quad(\mathrm{p}<0,05)$, artinya terdapat perbedaan selisih penurunan tekanan darah diastolik antara responden yang mendapat terapi napas dalam dengan responden yang mendapat terapi relaksasi otot progresif. Hasil penelitian menunjukkan bahwa pemberian terapi relaksasi otot progresif lebih besar penurunan tekanan darah dibandingkan dengan responden yang diberikan terapi napas dalam.

Dari hasil uji statistik dapat disimpulkan bahwa terdapat perbedaan penurunan tekanan darah pada kelompok yang mendapat terapi napas dalam dan kelompok yang mendapat terapi relaksasi otot progresif dimana penurunan tekanan darah pada responden kelompok yang mendapat terapi relaksasi otot progresif lebih besar dari kelompok yang mendapat terapi napas dalam. Menurut JNC (2003) seseorang yang melakukan aktifitas fisik secara teratur akan dapat menurunkan tekanan darah 4-9 $\mathrm{mmHg}$. Pada penelitian ini relaksasi otot progresif lebih mengandalkan aktifitas fisik dibandingkan dengan napas dalam yang hanya menggerakkan otot dada sehingga penurunan tekanan darah pada responden setelah diberikan relaksasi otot progresif lebih besar daripada napas dalam.

Perbedaan lain dikarenakan sebagian besar responden pada kelompok yang mendapat terapi relaksasi otot progresif mengaku selalu mengikuti senam lansia yang dilakukan di sekitar tempat tinggal mereka. Saat melakukan senam lansia, tekanan darah akan naik cukup banyak. Sebaliknya setelah senam selesai, tekanan darah akan menurun dan berlangsung selama 30-120 menit. Kalau senam dilakukan secara berulang-ulang dan teratur maka penurunan tekanan darah akan berlangsung lebih lama (Irkanda, 2008). Penurunan tekanan darah ini disebabkan karena terjadi pelebaran pada pembuluh darah dan relaksasi. Lama kelamaan, senam secara teratur dapat melemaskan pembuluh darah, sehingga tekanan darah menurun (Wijayakusuma, 2007).

Penurunan tekanan darah setelah diberikan terapi relaksasi otot progresif lebih besar dibandingkan dengan penurunan tekanan darah setelah diberikan terapi napas dalam karena pada relaksasi otot progresif sendiri, individu akan diberikan kesempatan untuk mempelajari bagaimana cara menegangkan sekelompok otot tertentu kemudian melepaskan ketegangan itu. Bila sudah dapat merasakan keduanya, klien mulai membedakan sensasi pada saat otot dalam keadaan tegang dan rileks. (Ramdhani \& Putra, 2006). Kegiatan napas dalam relaksasinya hanya terfokus pada pernapasan saja, sehingga cakupan sistem tubuh yang menjadi rileks hanya sedikit sedangkan relaksasi otot progresif dapat merilekskan hampir semua otot di tubuh.

Selain itu relaksasi otot progresif terdiri dari berbagai macam gerakan yang membuat responden menjadi tertarik dan bersemangat untuk mengikuti gerakangerakan yang diberikan. Dengan gerakan yang beragam responden tidak merasa bosan walaupun harus melakukan kegiatan selama 30 menit. Berbeda dengan latihan napas dalam tidak memiliki gerakan yang beragam hanya terdiri dari menghirup napas secara dalam, menahan kemudian 
menghembuskannya yang dilakukan dalam waktu 20 menit. Hal ini akan membuat responden merasa bosan melakukan hal yang sama dalam waktu tersebut dan akhirnya akan memecah konsentrasi responden dan latihan menjadi tidak optimal.

\section{KESIMPULAN DAN SARAN}

Berdasarkan hasil penelitian yang dilakukan mengenai perbedaan pengaruh terapi napas dalam dan terapi relaksasi otot progresif di Posyandu Lansia Kelurahan Surau Gadang Kecamatan Nanggalo, maka dapat diambil kesimpulan bahwa terdapat perbedaan penurunan tekanan darah pada responden setelah diberikan terapi napas dalam dan terapi relaksasi otot progresif dimana terapi relaksasi otot progresif lebih besar menurunkan tekanan darah daripada terapi napas dalam. Hal ini sangat erat kaitannya dengan karakteristik responden diantaranya faktor usia, kebiasaan merokok, aktifitas fisik dan diet.

Diharapkan lansia dengan hipertensi dapat melakukan relaksasi otot progresif untuk menurunkan tekanan darah dalam kehidupan sehari-hari. Untuk penelitian selanjutnya diharapkan dapat meneliti teknik relaksasi lainnya untuk menurunkan tekanan darah pada lansia dengan hipertensi.

\section{DAFTAR KEPUSTAKAAN}

Badan Kependudukan dan Keluarga BerencanaNasional. (2012). Lansia Siapa Peduli. Diakses pada tanggal 12 Maret 2012 dari http://www.bkkbn.go.id/siaranpers/ Pages/Lansia-Siapa-Perduli.aspx.

Clark, J (2012).What is Nitric Oxide and How Does It Work?. USA: Nutrition Express.

Dinas Kesehatan Kota Padang. (2011). Profil Kesehatan Kota Padang
Tahun 2010 Edisi 2011. Padang: DKK Kota Padang.

Irkanda, I. (2008). Hipertensi dan Pencegahan. Diakses tanggal 22 Januari 2013 dari http://mmm.via.ab_hypertensioneld ery.pdf.

Kuswardhani, RA Tuty. (2006). Penatalaksanaan Hipertensi pada Lanjut Usia. Jurnal Penyakit Dalam, 7(2), 135-140.

Meiner, S.E. (2011). Gerontologic Nursing Fourth Edition. United States of America: ELSEVIER MOSBY.

Nugroho, W. (2000). Keperawatan Gerontik. Jakarta: EGC.

Ramdhani, N., \& Putra, A. A. (2006). Pengembangan Multimedia Relaksasi. Jurnal Psikologi Volume 34 no. 2

Smeltzer, S.C \& Bare, B.G. (2002).Buku Ajar Keperawatan Medical Bedah Brunner and Sudarth, vol . I (edisi 8). AlihBahasa ; Monica Ester, Ellen Panggabean. Jakarta: EGC.

U.S. Department Of Health And Human Services. (2004). The Seventh Report of the Joint National Committee on Prevention, Detection, Evaluation, and Treatment of High Blood Pressure. Diakses tanggal 18 Oktober 2012 dari

http://www.nhlbi.nih.gov/guidelines /hypertension/jnc7full.html.

Wijayakusuma. (2007). Olahraga untuk Kesehatan Jantung. Diakses tanggal 24 Januari 2013 dari http://www.fjf.com/archieve/67895 47/dt/rb-rs/pdf. 
Wikipedia. (2012). Biological Functions of Nitric Oxide. Diakses tanggal 26 Juli 2012 dari http://en.wikipedia.org/wiki/ Biological_functions_of nitr ic oxide. 